\title{
Invited review: Effect of udder health management practices on herd somatic cell count
}

\author{
S. Dufour, ${ }^{\star}{ }^{1}$ A. Fréchette, ${ }^{*}$ H. W. Barkema, $† \ddagger$ A. Mussell,, and D. T. Scholl ${ }^{\star} \dagger$ \\ *Department of Pathology and Microbiology, Faculty of Veterinary Medicine, University of Montreal, C.P. 5000, St-Hyacinthe, Quebec, J2S 7C6, \\ Canada \\ †Canadian Bovine Mastitis Research Network, C.P. 5000, St-Hyacinthe, Quebec, J2S 7C6, Canada \\ $\ddagger$ Department of Production Animal Health, Faculty of Veterinary Medicine, University of Calgary, 3300 Hospital Drive NW, Calgary, Alberta, \\ T2N 4N1, Canada \\ §George Morris Centre, 225-150 Research Lane, Guelph, Ontario, N1G 4T2, Canada
}

\section{ABSTRACT}

A systematic review of the scientific literature on relationships between management practices used on dairy farms and herd somatic cell count (SCC) was undertaken to distinguish those management practices that have been consistently shown to be associated with herd SCC from those lacking evidence of association. Relevant literature was identified using a combination of database searches (PubMed, Medline, CAB, Agricola, and Web of Science) and iterative screening of references. To be included in the review, a manuscript had to be published after 1979 in French, English, or Dutch; study design had to be other than case report or case series; herds studied had to be composed of $\geq 40$ milking cows producing on average $\geq 7,000 \mathrm{~kg}$ of milk in $305 \mathrm{~d}$; interventions studied had to be management practices applied at the herd level and used as udder health control strategies; and SCC had to be measured using electronic cell counting methods. The 36 manuscripts selected were mainly observational cross-sectional studies; 8 manuscripts dealt exclusively with automatic milking systems and 4 with management of calves and heifers and its effect on SCC in early lactation heifers. Most practices having consistent associations with SCC were related to milking procedures: wearing gloves during milking, using automatic take-offs, using postmilking teat dipping, milking problem cows last, yearly inspection of the milking system, and use of a technique to keep cows standing following milking; all were consistently associated with lower herd SCC. Other practices associated with lower SCC were the use of a freestall system, sand bedding, cleaning the calving pen after each calving, surveillance of dry-cow udders for mastitis, use of blanket dry-cow therapy, parenteral selenium supplementation, udder

\footnotetext{
Received August 11, 2010.

Accepted October 5, 2010.

${ }^{1}$ Corresponding author: simon.dufour@umontreal.ca
}

hair management, and frequent use of the California Mastitis Test. Regarding SCC of heifers, most of the consistent associations reported were related to interventions made during the peripartum period. Studies on automatic milking systems have frequently reported elevation of the herd SCC following transition to the new system. These elevations seemed to be mediated both by the lack of monitoring of chronically infected cows and by an elevated incidence of intramammary infections. By assembling the results reported in many different studies, this review generates a more comprehensive understanding of the management practices influencing SCC and highlights areas of SCC control knowledge that lack evidence of effectiveness.

Key words: management, somatic cell count, systematic review, automatic milking system

\section{INTRODUCTION}

A vast body of literature reports associations between various management practices applied on dairy farms and different measures of udder health. Some of the udder health parameters that have been most frequently studied are the incidence of clinical mastitis, SCC, and, to a lesser extent, the pathogen-specific prevalence and incidence of IMI. As a measure of udder health, SCC is a very interesting and valuable measure. Somatic cell count is mainly determined by IMI and is therefore an excellent proxy to measure prevalence and even incidence of IMI whether clinical signs of mastitis are present or not (Dohoo and Leslie, 1991). In addition, SCC measurements can easily be obtained for research either from bulk milk (BMSCC) or as a herd average of individual cow (HSCC) measurements from DHI programs.

Finally and most importantly, BMSCC, along with total bacterial plate count, is used internationally as a standard for milk quality. For dairy producers worldwide, SCC is not only a measure of herd udder health performance, it is also a determinant of the market- 
ability of their milk. In a recent Canadian study, $88 \%$ of dairy producers claimed that they usually review the individual SCC data of their herd on the very same day the report becomes available (Dufour et al., 2010). Dairy producers are indeed very concerned with SCC and will frequently inquire about the management practices that could best help them achieve BMSCC reductions.

For dairy veterinary practitioners and extension agents, providing evidence-based advice to clients is a difficult task. The number of studies reporting associations between management practices and SCC is vast. In addition, because of the relative availability of SCC measurements, it is not uncommon to find studies reporting associations between SCC and management practices that are not even intended for use as udder health control strategies. Finally, in many studies, interventions are applied at the cow level without providing evidence for herd-level effects. These studies do not take into account the within-herd dynamics of IMI. Although these studies do provide important knowledge and understanding of mastitis epidemiology, the results observed when an intervention was applied to a few individuals within a herd can differ from the ones that would have been observed if the intervention had been applied to the whole herd.

The objective of this study was to perform a standardized review of the literature on associations between management practices used on dairy farms and herd-level SCC. A specific objective was to distinguish between management practices that have consistently shown association with SCC when applied at the herd level, and management practices for which evidence of an association with herd-level SCC is lacking.

\section{MATERIALS AND METHODS}

\section{Literature Search and Inclusion Criteria}

Five databases (PubMed, Medline, CAB, Agricola, and Web of Science) were searched on April 22, 2009, for original research published in French, English, or Dutch. To ensure that the retrieved manuscripts would be relevant for modern dairy herds, searches were restricted to manuscripts published later than 1979. Search strategies were developed with the help of a librarian and consisted of Boolean search statements using medical subject heading (MeSH) terms specific to each database. The MeSH terms used were descriptors of the population (dairy cows) and outcome (SCC) of interest; MeSH is a system of medical metadata consisting of sets of terms naming descriptors in a hierarchical structure that permits searching at various levels of specificity. The Boolean search strategies and MeSH terms used were "cattle" and "cell count" and "milk" for Medline and PubMed; "dairy cattle" and "somatic cell count" for CAB; "cow" and "somatic cell count" for Agricola; and "cow" or "cows" or "cattle" or "bovine" and "somatic cell count" for Web of Science. Manuscripts retrieved from the different databases were collated and duplicates were eliminated. Only manuscripts for which an abstract was available were considered.

To be included in the review, a manuscript had to meet the additional following criteria:

(1) Intervention studied was a management practice applied or observed at the herd level and used as an udder health control strategy;

(2) SCC was measured using cell counting methods rather than California Mastitis Test (CMT) or Rapid Mastitis Test (Immucell, Portland, ME);

(3) Study design was not case report or case series;

(4) Mean 305-d milk production of the herds studied was $\geq 7,000 \mathrm{~kg}$; and

(5) Mean herd size of the herds studied was $\geq 40$ milking cows.

Thresholds for the last 2 inclusion criteria were defined based on the 25th percentiles for herds participating in dairy herd improvement programs in Canada in 2008 (Sylvia Lafontaine, Valacta, Sainte-Anne-de-Bellevue, Quebec, personal communication). These thresholds were defined to select studies conducted on dairy herds comparable to modern dairy herds found in North America and in most European countries.

A search protocol was developed based on the recommendations of Greenhalgh and Peacock (2005), who identified electronic search and reference tracking as the most powerful methods for identifying high quality sources. In short, all abstracts obtained were reviewed concurrently by 2 of the authors (S.D. and A.F.) using the previously defined inclusion criteria. All reviewers were blinded to the authors, journal, and year of publication of the manuscripts. At this stage of the reviewing process, inclusion criteria were not strictly applied to not exclude any relevant manuscript. Whenever the 2 reviewers disagreed on the selection of an abstract, a third author (D.T.S.) was asked to review the abstract and decide on its eligibility for inclusion. Full texts of the selected abstracts were then obtained, reviewed, and selected in a similar manner with strict application of the inclusion criteria. Whenever information relative to inclusion criteria was lacking in a manuscript, companion papers were consulted or efforts were made to contact authors by electronic communication to obtain the missing information. Finally, the list of references quoted in each paper was screened to find potentially relevant manuscripts that had not been identified by 
the database searches. Additional manuscripts found were reviewed as described previously, and their reference lists were screened until complete depletion.

\section{Data Abstraction}

Two of the authors (S.D. and A.F.) concurrently abstracted the following information from the selected manuscripts on a standardized form: study design, study location, study period, number of herds, explanatory variables studied, and specific outcome variables studied. For studies with multiple published papers, the most complete paper was used as the primary source of information and the other reports were used for supplemental information. For each manuscript, one of the authors (S.D.) abstracted or computed effect estimates for each management practice for which results were reported. Only one effect estimate per study per comparison was computed for a given management practice. When a study reported more than one effect estimate or more than one measure of association with SCC for a specific practice, priority was given to herd-effect estimates rather than to group-specific effect estimates, then to incidence data rather than to prevalence data, then to continuous measures of SCC or SCS rather than to proportion of cows over a given SCC or SCS threshold, and finally to multivariable analyses rather than to unadjusted analyses or to descriptive results. When more than one multivariable model was presented, the most complete model was used.

Standard error for each effect estimate was abstracted, computed, or imputed using variance imputation methods (Follmann et al., 1992; Philbrook et al., 2007; O'Rourke and Greenland, 2008) and 95\% CI were computed using the obtained effect estimate and standard errors. These 95\% CI were adjusted using the Bonferroni correction (Abdi, 2007) whenever multiple comparisons were made.

\section{Analytical Methods}

Associations between management practices and SCC were first investigated using forest plots, a graphical representation summarizing the individual effects that were observed in the selected studies (Khan et al., 2003). In view of the large amount of heterogeneity among SCC measurements used, definitions of explanatory variables, and measures of association reported, no attempt was made to compute pooled effect estimates. Hence, formal analyses were restricted to nonparametric comparisons of study results. Each of the reported associations between a management practice and SCC was classified as being toward lower SCC, a null effect, or toward higher SCC. For those studies employing categorical-scale measurement of herd SCC or of herdproportion of high SCC cows, this was done by noting if the odds ratio of belonging to the lower SCC category when using the investigated practice was greater than, equal to, or lower than the null value of 1.0, respectively. For studies investigating the incidence of SCC increases, this was done by noting if the incidence ratio comparing incidences in herd using and not using the investigated practice was lower than, equal to, or greater than the null value of 1.0, respectively. Finally, for studies investigating differences of herd SCC or of herd-proportion of high SCC cows between herds using and not using a practice, this was done by noting if the difference was lower than, equal to, or greater than the null value of 0.0 , respectively. A reported effect was considered globally statistically significant whenever its corrected 95\% CI did not include the null effect.

Management practice effect estimates that were reported in multiple articles were tested for consistency of the association with SCC by a binomial test, consistency being defined as continually having an association in a given direction. This binomial test estimates the probability of observing a given proportion of associations in one direction, under the null hypothesis of no association (unidirectional sign test; O'Rourke and Greenland, 2008). We must emphasize that this binomial test does not have high statistical power, especially when very few reports of effect estimates are available. We therefore used a more liberal $P$-value of 0.15 as the threshold for statistical significance of the binomial test.

\section{RESULTS}

A flowchart describing the selection process of the relevant literature is presented in Figure 1. During the full-text reviewing process, important information related to our inclusion criteria was missing for 22 articles. For 2 articles, missing information could be found in companion papers. Authors of the remaining 20 manuscripts were contacted electronically and asked to provide the needed information; answers were obtained for 14 manuscripts and 8 were included in the review. For 6 of the manuscripts with missing information (Vecht et al., 1989; Hogeveen et al., 2001; Gygax and Nosal, 2006; Köster et al., 2006a,b; Stup et al., 2006), we were unable to obtain a reply from the authors even after multiple attempts to contact them; these manuscripts were not included in the review.

The main features of the 36 manuscripts included in this study can be found in Table 1. All studies included in this systematic review were observational studies; the majority used a cross-sectional study design $(\mathrm{n}=28)$ or a combination of cross-sectional and before-and-after 




Figure 1. Flowchart describing the process of identifying relevant literature on associations between dairy farm management practices and herd SCC. Footnote 1: excluded after multiple unsuccessful attempts to obtain missing information from authors.

designs $(\mathrm{n}=6)$. One study used strictly a before-andafter study design (Rasmussen et al., 2001) and only one study used a longitudinal cohort design (Bareille et al., 1998).

Heterogeneity in exposure measurements was noticeable. For 25 manuscripts, questionnaires were used to measure part or all of the management practices of interest; only 2 independent studies used the exact same questionnaire (Svensson et al., 2006; Nyman et al., 2009). For the remaining studies, the questionnaires were developed specifically for the project. Only one study reported validating, although only partly, the questionnaire used (Barnouin et al., 2004).
In many manuscripts, more than one SCC-related outcome was investigated. Substantial heterogeneity among outcomes used was found between manuscripts (see Table 1). Briefly, 3 different outcomes were reported:

1) Herd- or group-specific SCC or SCS [estimated from bulk milk $(\mathrm{n}=14)$ or from mean individual cow SCC $(n=16)]$,

2) Prevalence of cows with an SCC over a specific threshold $(n=6)$, and

3) Proportion of cows with an SCC increasing from below to above a specific threshold over a defined period $(\mathrm{n}=2)$. 
Table 1. Characteristics of manuscripts on associations between management practices and measures of SCC (bulk milk or individual cow SCC in cells/mL, as measured by DHI organizations)

\begin{tabular}{|c|c|c|c|c|c|c|}
\hline $\begin{array}{l}\text { Manuscript } \\
\text { and index number }\end{array}$ & $\begin{array}{l}\text { Country } \\
\text { (state) }\end{array}$ & $\begin{array}{l}\text { Study } \\
\text { period }\end{array}$ & $\begin{array}{l}\text { Population } \\
\text { (herds) }\end{array}$ & $\begin{array}{l}\text { Study } \\
\text { design }^{1}\end{array}$ & Outcome & $\begin{array}{l}\text { Intervention } \\
\text { or observation }\end{array}$ \\
\hline 1. Bach et al., 2008 & Spain & 2006 & 47 & CS & Herd mean ${ }^{2}$ bulk milk SCC (BMSCC) & Multiple $^{3}$ \\
\hline 2. Bareille et al., 1998 & France & 1995-1996 & 237 & $\mathrm{LC}$ & $\begin{array}{l}\text { Incidence of cows increasing } \\
\text { to } \mathrm{SCC}>200,000 \text { cells } / \mathrm{mL}\end{array}$ & Multiple \\
\hline 3. Bareille et al., 2000 & France & $1995-1997$ & 228 & CS & $\begin{array}{l}\text { Herd } \% \text { of heifers with SCC }>200,000 \\
\text { cells } / \mathrm{mL} \text { between } 7 \text { and } 45 \text { DIM }\end{array}$ & Heifer management \\
\hline 4. Barkema et al., $1998 \mathrm{a}^{4}$ & Netherlands & $1992-1994$ & 274 & CS & $\begin{array}{l}\text { Herd geometric mean BMSCC: } \\
\text { Low }(<150,000 \text { cells } / \mathrm{mL}, \mathrm{n}=85) \\
\text { Medium }(151-250,000 \text { cells } / \mathrm{mL}, \mathrm{n}=133) \\
\text { High }(>250,000 \text { cells } / \mathrm{mL}, \mathrm{n}=56)\end{array}$ & Culling rate \\
\hline 5. Barkema et al., $1998 \mathrm{~b}^{4}$ & Netherlands & 1992-1994 & 201 & CS & Same as Barkema et al., 1998a & Multiple \\
\hline 6. Barnouin et al., 2004 & France & 1999-2001 & 534 & CS & $\begin{array}{l}\text { Herd mean SCS: } \\
\text { Low (percentiles } 0-5 \text { of SCS, } \mathrm{n}=326 \text { ) } \\
\text { Medium (percentiles } 50-55 \text { of SCS, } \mathrm{n}=208 \text { ) }\end{array}$ & Multiple \\
\hline 7. Bartlett et al., 1992 & $\mathrm{US}(\mathrm{OH})$ & 1988-1989 & 48 & CS & $\log _{n}$ of herd mean BMSCC & Multiple \\
\hline 8. Bewley et al., 2001 & US (WI) & 1999 & 244 & CS & Herd mean SCS & Barn design, bedding, and cooling method \\
\hline 9. Billon and Tournaire, 2002 & France & 2001 & 101 & $\mathrm{BA}, \mathrm{CS}$ & Herd mean BMSCC & Use of automatic milking system (AMS) \\
\hline 10. De Vliegher et al., 2004 & Belgium & $1999-2000$ & 159 & $\mathrm{CS}$ & $\begin{array}{l}\text { Herd geometric mean SCC of } \\
\text { heifers between } 5 \text { and } 14 \text { DIM }\end{array}$ & Management of heifers \\
\hline 11. Ellis et al., 2007 & UK & $2003-2004$ & 28 & CS & Herd geometric mean BMSCC & Cow cleanliness \\
\hline 12. Erskine et al., $1987 \mathrm{a}^{5}$ & US (PA) & - & 32 & CS & $\begin{array}{l}\text { Herd mean SCC: } \\
\text { Low }(\leq 150,000 \text { cells } / \mathrm{mL}, \mathrm{n}=16) \\
\text { High }(\geq 700,000 \text { cells } / \mathrm{mL}, \mathrm{n}=16)\end{array}$ & Multiple \\
\hline 13. Erskine et al., $1987 \mathrm{~b}^{5}$ & US (PA) & - & 32 & CS & Same as Erskine et al., 1987a & Se, vitamin $A, E$, and $\beta$-carotene \\
\hline $\begin{array}{l}\text { 14. Erskine and } \\
\text { Eberhart, } 1991\end{array}$ & US (PA) & - & 71 & CS & $\begin{array}{l}\text { Herd mean SCC: } \\
\text { Low }(\leq 250,000 \text { cells } / \mathrm{mL}, \mathrm{n}=24) \\
\text { High }(>700,000 \text { cells } / \mathrm{mL} \text { and } \\
\text { high IMI prevalence, } \mathrm{n}=47)\end{array}$ & $\begin{array}{l}\text { Postmilking teat disinfection } \\
\text { and use of dry-cow therapy }\end{array}$ \\
\hline 15. Fulwider et al., 2007 & $\begin{array}{l}\text { US }(W I, M N \\
\text { NY, IA, IN) }\end{array}$ & $2005-2006$ & 113 & $\mathrm{CS}$ & Herd mean SCC & $\begin{array}{l}\text { Stall length, width, bedding, } \\
\text { and cow cleanliness }\end{array}$ \\
\hline 16. Goodger et al., 1988 & $\mathrm{US}(\mathrm{CA})$ & $1984-1985$ & 50 & CS & $\begin{array}{l}\text { Herd mean SCC: } \\
\text { Low }(<264,000 \text { cells } / \mathrm{mL}, \mathrm{n}=25) \\
\text { High }(>264,000 \text { cells } / \mathrm{mL}, \mathrm{n}=25)\end{array}$ & Multiple \\
\hline 17. Hutton et al., $1990^{6}$ & US (WA) & $1986-1987$ & 59 & CS & $\begin{array}{l}\% \text { of cows with SCS } \leq 4 \text { : } \\
\text { Low }(28 \text { herds with the highest } \%) \\
\text { High }(31 \text { herds with the lowest } \%)\end{array}$ & Multiple \\
\hline 18. Hutton et al., $1991^{6}$ & US (WA) & $1986-1987$ & 59 & $\mathrm{CS}$ & Same as Hutton et al., 1990 & Multiple \\
\hline 19. Jayarao et al., 2004 & US (PA) & $2000-2001$ & 126 & CS & Herd geometric mean BMSCC & Multiple \\
\hline 20. Khaitsa et al., 2000 & $\mathrm{US}(\mathrm{OH})$ & $1996-1997$ & 186 & CS & Herd mean BMSCC & Multiple \\
\hline 21. Klungel et al., $2000^{7}$ & Netherlands & $1996-1998$ & 105 & $\mathrm{BA}, \mathrm{CS}$ & $\log _{n}$ of herd mean BMSCC & Use of AMS and milking frequency \\
\hline 22. Lievaart et al., $2007^{4}$ & Netherlands & $1992-1994$ & 246 & $\mathrm{CS}$ & $\begin{array}{l}\text { Herd monthly SCC (within } 3 \text { categories) } \\
\text { Low }(<150,000 \text { cells } / \mathrm{mL}, \mathrm{n}=81) \\
\text { Medium }(150-200,000 \text { cells } / \mathrm{mL}, \mathrm{n}=86) \\
\text { High }(>200,000 \text { cells } / \mathrm{mL}, \mathrm{n}=79)\end{array}$ & Multiple \\
\hline 23. Nyman et al., 2009 & Sweden & $2005-2006$ & 72 & CS & $\begin{array}{l}\text { Herd } \% \text { of heifers with SCC } \\
\geq 200,000 \text { cells } / \mathrm{mL} \text { at first test } \\
\log _{\mathrm{n}} \text { of heifers SCC at first test }\end{array}$ & Management of heifers \\
\hline
\end{tabular}


Table 1 (Continued). Characteristics of manuscripts on associations between management practices and measures of SCC (bulk milk or individual cow SCC in cells/mL, as measured by DHI organizations)

\begin{tabular}{|c|c|c|c|c|c|c|}
\hline $\begin{array}{l}\text { Manuscript } \\
\text { and index number }\end{array}$ & $\begin{array}{l}\text { Country } \\
\text { (state) }\end{array}$ & $\begin{array}{l}\text { Study } \\
\text { period }\end{array}$ & $\begin{array}{l}\text { Population } \\
\text { (herds) }\end{array}$ & $\begin{array}{l}\text { Study } \\
\text { design }^{1}\end{array}$ & Outcome & $\begin{array}{l}\text { Intervention } \\
\text { or observation }\end{array}$ \\
\hline 24. Rasmussen et al., $2001^{8}$ & Denmark & $1997-2000$ & 69 & $\mathrm{BA}$ & $\begin{array}{l}\text { Herd mean SCC } \\
\% \text { of cows increasing }>200,000 \text { cells } / \mathrm{mL} \\
\% \text { of cows with } \mathrm{SCC}>200,000 \text { cells } / \mathrm{mL}\end{array}$ & Use of AMS \\
\hline 25. Rasmussen et al., $2002^{8}$ & Denmark & $1997-2001$ & 98 & $\mathrm{BA}, \mathrm{CS}$ & $\log _{10}$ of herd mean BMSCC & Use of AMS and self-monitoring program \\
\hline 26. Rodrigues et al., 2005 & US (WI) & $2001-2004$ & 180 & CS & $\begin{array}{l}\text { Herd mean } \log _{10} \text { BMSCC and SCS } \\
\text { Herd mean SCS } \\
\% \text { of cows with SCS }>4 \\
\text { Herd mean BMSCC }(\text { categorical }): \\
\text { Low }(<250,000 \text { cells } / \mathrm{mL}, \mathrm{n}=36) \\
\text { Medium }(250-400,000 \text { cells } / \mathrm{mL}, \mathrm{n}=83) \\
\text { High }(>400,000 \text { cells } / \mathrm{mL}, \mathrm{n}=61)\end{array}$ & Multiple \\
\hline 27. Smith and Ely, 1997 & US (GA) & 1994 & 178 & CS & Herd mean SCC & Multiple \\
\hline 28. Smith et al., 2002 & US (39 states) & $1998-2000$ & 10,754 & CS & $\begin{array}{l}\text { Herd mean SCC and SCS } \\
\% \text { of cows with SCS } 0-3 \text { and } 7-9\end{array}$ & Milking frequency \\
\hline 29. Svensson et al., 2006 & Sweden & $1998-2000$ & 102 & CS & Heifer SCC $\geq 200,000$ cells $/ \mathrm{mL}$ at first test & Heifer management \\
\hline $\begin{array}{l}\text { 30. Van der Vorst and } \\
\text { Hogeveen, } 2000^{7}\end{array}$ & Netherlands & $1997-1999$ & 167 & $\mathrm{BA}, \mathrm{CS}$ & $\log _{n}$ of herd mean BMSCC & Use of AMS and milking frequency \\
\hline $\begin{array}{l}\text { 31. Van der Vorst } \\
\text { et al., } 2002^{7,8}\end{array}$ & $\begin{array}{l}\text { Denmark, } \\
\text { Germany, and } \\
\text { Netherlands }\end{array}$ & $1997-2001$ & 729 & $\mathrm{BA}, \mathrm{CS}$ & $\log _{n}$ of herd mean BMSCC & Use of AMS and milking frequency \\
\hline $\begin{array}{l}\text { 32. Van der Vorst } \\
\text { et al., } 2003^{7}\end{array}$ & Netherlands & $1997-2001$ & 114 & CS, BA & Herd mean BMSCC (categorized) & Use of AMS, housing, milking, and others \\
\hline $\begin{array}{l}\text { 33. Van der Vorst } \\
\text { and Ouweltjes, } 2003^{7}\end{array}$ & Netherlands & $1997-2002$ & $\begin{array}{l}28 \\
\text { (using } \\
\text { AMS) }\end{array}$ & CS & $\begin{array}{l}\log _{\mathrm{n}} \text { of herd mean BMSCC: } \\
\text { Low }(<170,000 \text { cells } / \mathrm{mL}, \mathrm{n}=5) \\
\text { Medium }(170-265,000 \text { cells } / \mathrm{mL}, \mathrm{n}=14) \\
\text { High }(>265,000 \text { cells } / \mathrm{mL}, \mathrm{n}=9)\end{array}$ & Housing, milking, and others in AMS herds \\
\hline 34. Weiss et al., 1990 & US $(\mathrm{OH})$ & - & 9 & CS & Herd mean BMSCC & Vitamin $\mathrm{E}$ and Se \\
\hline 35. Wenz et al., 2007 & US (21 states) & 2002 & 1,013 & CS & $\begin{array}{l}\text { Producer-reported mean BMSCC: } \\
\text { Low }(<200,000 \text { cells } / \mathrm{mL}, \mathrm{n}=264) \\
\text { Medium }(200-400,000 \text { cells } / \mathrm{mL}, \mathrm{n}=569) \\
\text { High }(>400,000 \text { cells } / \mathrm{mL}, \mathrm{n}=180)\end{array}$ & Multiple \\
\hline 36. Wilson et al., 1995 & US (NY, PA) & $1992-1994$ & 76 & CS & Herd mean BMSCC & Segregation of Staph. aureus infected cows \\
\hline
\end{tabular}

${ }^{1} \mathrm{CS}=$ cross-sectional study; $\mathrm{BA}=$ before-and-after study; $\mathrm{LC}=$ longitudinal cohort study

${ }^{2}$ Mean is the arithmetic mean unless specified otherwise.

${ }^{3}$ Multiple = study reporting a wide range of management practices.

${ }^{4-8}$ Studies sharing the same superscript number were conducted using data from some of the same herds during the same period. 
Herd- or group-specific SCC or SCS were frequently $(\mathrm{n}=12)$ categorized in 2 (low and high) or 3 (low, medium, and high) categories. Definitions of each category were specific to each study, with low SCC herd definitions ranging from $<150,000$ cells $/ \mathrm{mL}$ to $<264,000$ cells $/ \mathrm{mL}$, and high SCC herd definitions ranging from $>200,000$ cells $/ \mathrm{mL}$ to $>700,000$ cells $/ \mathrm{mL}$. In 4 manuscripts (Bareille et al., 2000; De Vliegher et al., 2004;

Table 2. Summary of the results of direction of associations estimated between dairy farm management practices and measures of SCC that were reported by more than one study

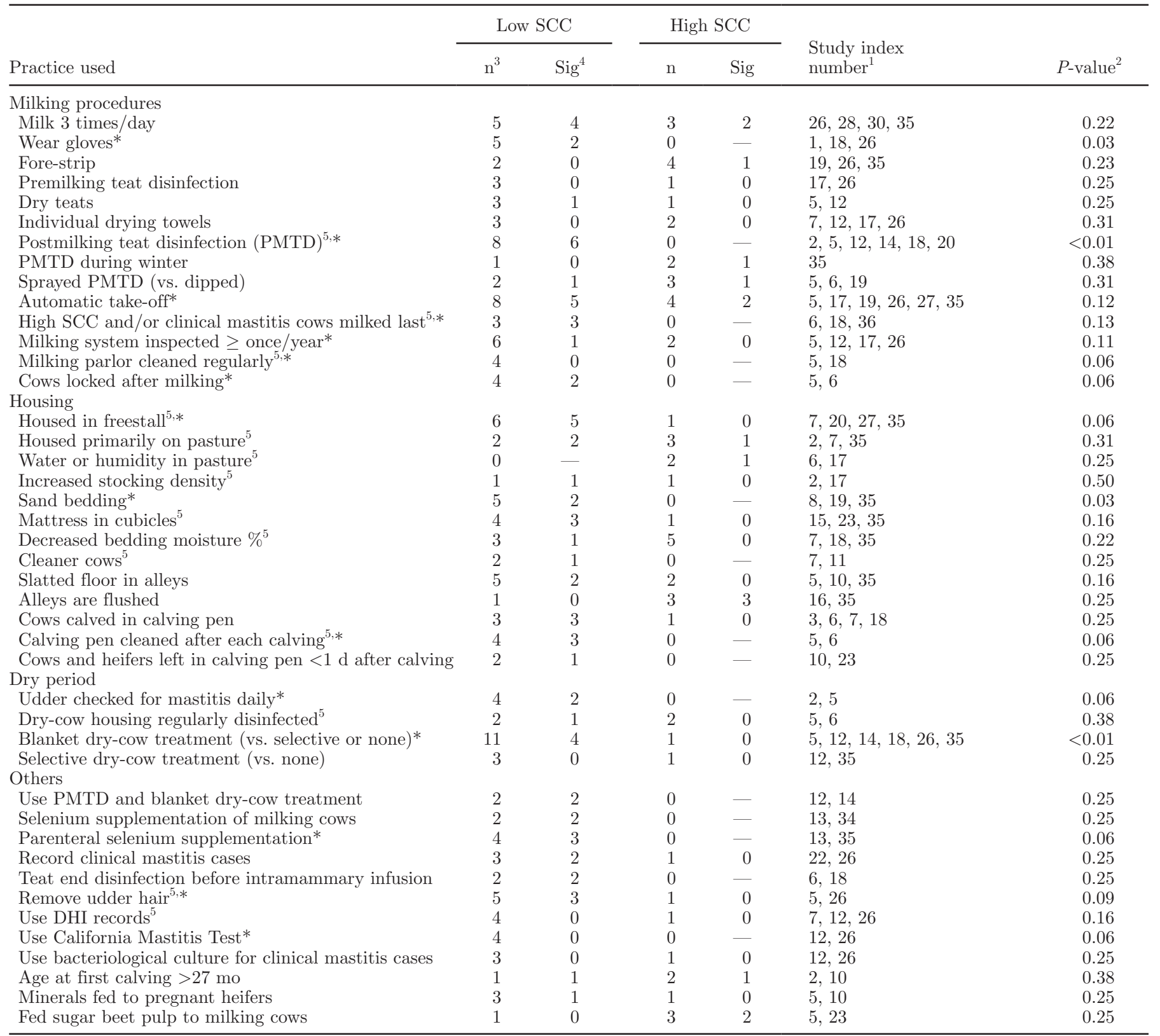

${ }^{1}$ Study identification index number as reported in Table 1; because many studies compared more than 2 groups of herds, the number of low SCC and high SCC comparisons will not necessarily add up to the number of studies reporting them.

${ }^{2} P$-value of the binomial test of obtaining the observed number of comparisons in a given direction under the null hypothesis of no association between the practice and SCC (one-sided sign test).

${ }^{3}$ No. of comparisons with the mentioned direction of effect.

${ }^{4}$ No. of significant comparisons $(P<0.05$, multiple comparisons adjusted using the Bonferroni correction) with the mentioned direction of effect.

${ }^{5}$ Noticeable differences between explanatory variable definition or comparison groups used among studies.

*Practices demonstrating a consistent association with SCC $(P<0.15)$. 
High SCC

Management practice

(N) Milking procedures

Cow-by-cow premilking preparation and
No. of milkers per month

No. of milking units per person

No. of cows milked per man per hour

attachment sequence

Use paper towels (vs. cloth towels)

Years of postmilking teat disinfection (PMTD)

Teat dip applicator cleaned after each milking

PMTD using chlorhexidine

High-producing cows milked first

Rodrigues et al., 2005

Rodrigues et al., 2005

Rodrigues et al., 2005

Hutton et al., 1990

Barkema et al., 1998b

Bach et al., 2008

Barkema et al., 1998b

Barnouin et al., 2004

Erskine and Eberhart, 199

Hutton et al., 1990

\section{Milking system}

Minimum vacuum $(\mathrm{kPa})$ in short

milk tube at $2 \mathrm{~kg} / \mathrm{min}$ flow

Disinfectant used in backflush solution

Housing

Cubicles rather than bedding packed system

Lying space accessibility

Manure packed system (vs. other types of housing)

Bedding treated with superphosphate

(vs. treated with a drying product)

Clean bedding area

Newspapers as bedding for milking cows

Stall length and width for rubber-filled

mattress stalls

Mean size of air inlet per row of cubicles

Peripartum period

Bedding $\%$ of dry matter in calving pens

Calving pen floor slatted

No outside area for peripartum cows

(vs. dry-lot or pasture)

No. of days after calving milk is added to bulk tank Dry period

Cephapirin benzathine used as dry cow treatment

(vs. other dry cow treatment products)

Teat disinfection before intramammary

infusion at dry-off

Teat disinfection after intramammary

infusion at dry-off

Years of blanket dry cow treatment

Use coliform mastitis vaccine

Barkema et al., 1998b

Hutton et al., 1991

Bareille et al., 1998 Bareille et al., 1998

Wenz et al., 2007

Bareille et al., 1998

Barkema et al., 1998b

Bartlett et al., 1992

Goodger et al., 1988

Wenz et al., 2007

Fulwider et al., 2007

Barkema et al., 1998b

Hutton et al., 1990

De Vliegher et al., 2004

Wenz et al., 2007

Barkema et al., 1998b

Khaitsa et al., 2000

Barnouin et al., 2004

Barnouin et al., 2004

Barkema et al., 1998b

Wenz et al., 2007
Frequency per day that cubicles are cleaned

Clean water troughs

Study

Management practice

\section{Milking procedures}

Wet premilking teat preparation (vs. dry)

before first-lactation cows are milked
Premilking teat disinfection with a foaming product

Wash only dirty teats before milking

Wet premilking teat preparation

with towels from a bucket

Lag time $\geq 2$ min between beginning of premilking preparation and attachment of the unit

No written milking procedures

Use hired milkers

Premilking teat preparation time $\leq 30 \mathrm{~s}$

PMTD using latex barrier with germicide

Vacuum not turned off before unit removal

High SCC cows and clinical mastitis

cases milked with a specific unit

Milking units rinsed, cleaned, or disinfected

Housing

Loose straw yard (vs. other types of housing)

Tie-stall or outside lot (vs. loose housing)

Free access of the herd to an

enclosure from the cow shed

Free access to cow shed from

pasture during bad weather

Barn design (no. of rows of cubicles per pen)

Quantity of manure in bedding area

Exercise area of milking cows scraped $\leq 1$ time/d

Study

Barnouin et al., 2004

Barnouin et al., 2004

Barkema et al., 1998b

Barkema et al., 1998b

Erskine et al., 1987a

Rodrigues et al., 2005

Bartlett et al., 1992
Bartlett et al., 1992

Erskine and Eberhart, 1991

Hutton et al., 1991

Barnouin et al., 2004

Nyman et al., 2009

\section{Peripartum period}

Having clean calving pen

Calving pen used for sick cows

Barkema et al., 1998b

De Vliegher et al., 2004

Dry period

Dry cows housed in a different location than

milking cows (vs. another area of the same shed)

$\%$ of dry cows cubicles with $>10 \%$

manure in last meter

$\%$ of dry cows with $>30 \%$ of udder

covered with manure

Barnouin et al., 2004

Bewley et al., 2001

Barnouin et al., 2004

Barnouin et al., 2004

Barkema et al., 1998b

Barkema et al., 1998b 
Table 3 (Continued). Management practices significantly associated with SCC and for which effect estimates were reported only once among 36 published articles

\begin{tabular}{|c|c|c|c|}
\hline \multicolumn{2}{|l|}{ Low SCC } & \multicolumn{2}{|l|}{ High SCC } \\
\hline Management practice & Study & Management practice & Study \\
\hline \multicolumn{2}{|l|}{ Culling and conformation } & \multicolumn{2}{|l|}{ Culling and conformation } \\
\hline Percentage of herd first-lactation cows & Bareille et al., 1998 & Monthly percentage of cows culled for mastitis & Rodrigues et al., 2005 \\
\hline Cows culled when at least one damaged teat & Barnouin et al., 2004 & Percentage of cows culled for high SCC & Barkema et al., 1998a \\
\hline Percentage of cows culled for teat lesions & Barkema et al., 1998a & Percentage of dry cows with udder below hock & Barkema et al., 1998b \\
\hline Percentage of cows culled for udder shape & Barkema et al., 1998a & $\geq 10 \%$ cows with udder below hock & Bareille et al., 1998 \\
\hline Cows culled when at least 3 clinical mastitis cases & Barnouin et al., 2004 & & \\
\hline \multicolumn{2}{|l|}{ Heifer and calf management } & \multicolumn{2}{|l|}{ Heifer and calf management } \\
\hline Calves separated from dam immediately at calving & Wenz et al., 2007 & Heifers checked for mastitis $<2$ wk before calving & Barnouin et al., 2004 \\
\hline Heifers checked for mastitis $>8$ wk before calving & Barnouin et al., 2004 & $\begin{array}{l}\text { Heifers moved to confined housing on } \\
\text { calving day (vs. before calving) }\end{array}$ & Svensson et al., 2006 \\
\hline Frequency at which heifers are checked for mastitis & Lievaart et al., 2007 & First-lactation cows calved in group & Nyman et al., 2009 \\
\hline $\begin{array}{l}\text { Introduction of heifers to milking cows } \\
\text { day of calving (vs. before calving) }\end{array}$ & Bareille et al., 2000 & $\begin{array}{l}\text { First-lactation cows milked in calving pen } \\
\text { during the colostrum period }\end{array}$ & Nyman et al., 2009 \\
\hline First-lactation cows calved in a calvingpen & Barnouin et al., 2004 & Fly problem more important than other years & De Vliegher et al., 2004 \\
\hline $\begin{array}{l}\text { End term heifers kept with dry-cows } \\
\text { when not on pasture }\end{array}$ & De Vliegher et al., 2004 & Heifers pregnant from AI or bull (vs. AI only) & De Vliegher et al., 2004 \\
\hline $\begin{array}{l}\text { Fly control in heifers on pasture } \\
\text { (pour-on or } 2 \text { ear tags) }\end{array}$ & De Vliegher et al., 2004 & $\begin{array}{l}\text { Use of different types of restraining devices } \\
\text { for first-lactation cows during milking }\end{array}$ & Svensson et al., 2006 \\
\hline Deworming all heifers (vs. some or none) & De Vliegher et al., 2004 & $\begin{array}{l}\text { Clipping heifers udder long before calving or } \\
\text { no clipping (vs. clipping around calving) }\end{array}$ & De Vliegher et al., 2004 \\
\hline \multicolumn{2}{|l|}{ Nutrition of calves and heifers } & \multicolumn{2}{|l|}{ Nutrition of calves and heifers } \\
\hline Calves are fed milk replacer & Lievaart et al., 2007 & Calves are fed high SCC milk & Barkema et al., 1998b \\
\hline Type of roughage at weaning & Svensson et al., 2006 & Calves are fed milk with antibiotic residues & Barkema et al., 1998b \\
\hline Percentage of corn silage in transition diet & Bareille et al., 2000 & Calves drinking in dirty bucket & Barkema et al., 1998b \\
\hline $\begin{array}{l}\text { Corn silage given at calving and onward } \\
\text { (vs. no corn silage given) }\end{array}$ & Nyman et al., 2009 & $\begin{array}{l}\text { Kilograms of concentrates fed to heifers } \\
11-16 \text { mo of age }\end{array}$ & Svensson et al., 2006 \\
\hline $\begin{array}{l}\text { End term heifers supplemented with other than } \\
\text { hay, straw, sugar pulp, or silage during summer }\end{array}$ & De Vliegher et al., 2004 & $\begin{array}{l}\text { Protein content and amount } \\
\text { of concentrates in transition diet }\end{array}$ & Bareille et al., 2000 \\
\hline $\begin{array}{l}\text { Weeks before calving, heifers are } \\
\text { introduced to lactating ration }\end{array}$ & Svensson et al., 2006 & At pasture, heifers drink water from river & Barnouin et al., 2004 \\
\hline \multicolumn{4}{|l|}{ Nutrition during transition period } \\
\hline Lower calcium supply during late pregnancy & Barnouin et al., 2004 & & \\
\hline $\begin{array}{l}\text { No. of days after calving that } \\
\text { max concentrates is fed }\end{array}$ & Barkema et al., 1998b & & \\
\hline \multicolumn{2}{|l|}{ Nutrition of milking cows } & \multicolumn{2}{|l|}{ Nutrition of milking cows } \\
\hline Supplement with minerals during summer & Barkema et al., 1998b & Percentage of forages being corn silage & Bareille et al., 1998 \\
\hline \multirow[t]{2}{*}{ Supplement with $\mathrm{NaCl}$} & Barnouin et al., 2004 & $\begin{array}{l}\text { Feed served outside in an uncovered feeding area } \\
\text { (vs. in freestall or covered outside feeding area) }\end{array}$ & Smith and Ely, 1997 \\
\hline & & Vitamin A-D-E supplementation & Wenz et al., 2007 \\
\hline
\end{tabular}

Erskine et al., 1987b

Barnouin et al., 2004

Rodrigues et al., 2005 De Vliegher et al., 2004

Barkema et al., 1998b
Clinical mastitis management

Clinical mastitis suspected when painful udder

Mastitis detection by checking foremilk for clots
Barnouin et al., 2004

Barnouin et al., 2004 Has written treatment protocol for clinical mastiti Mastitis treatment done by farmer (vs. veterinarian involved) treatments usually given 
Svensson et al., 2006; Nyman et al., 2009), a measure of SCC in heifers at the beginning of their first lactation was the outcome studied. In these studies, practices investigated were related to calf and heifer management from birth up to a few weeks following calving.

Results for management practices with effect estimates reported by 2 or more studies are summarized in Table 2. For many of the practices investigated, effect estimates were reported only once. Furthermore, many practices were sometimes measured in such a specific manner in one study that reporting the results obtained with those of other studies would be misleading. These results are therefore presented individually. For these distinct practices, a list of the practices with statistically significant associations is presented in Table 3 . Other single-reported practices for which nonsignificant associations were obtained are presented in supplementary material online (Supplementary Table available at http://www.journalofdairyscience.org/).

In addition to the results reported in Table 3, one study by Lievaart et al. (2007) used data collected by Barkema et al. (1998b) to specifically investigate associations between management practices and variation of HSCC within low $(<150,000$ cells $/ \mathrm{mL})$, medium $(150,000-200,000$ cells $/ \mathrm{mL})$, and high ( $>200,000$ cells / $\mathrm{mL}$ ) SCC categories. In complement to the findings of Barkema et al. (1998b), they observed that, within the low SCC category, herds using a wet premilking teat preparation had higher HSCC. They also found conflicting significant associations from one season to another for herds using a technique to keep cows standing after milking. During winter, for herds in the low SCC category, feeding cows or feeding and locking cows in headlocks following milking was associated with higher HSCC; during summer, the reverse association was observed, with herds in that same low SCC category having lower HSCC when using these techniques. In this same study, the number of days before milk was added to the bulk tank following calving was negatively associated with HSCC within the low SCC category. Opposite associations were also observed in this study for feeding fresh milk to calves: within the low SCC category, this practice was associated with higher HSCC, whereas within the high SCC category, it was associated with lower HSCC. Finally, similarly to Barkema et al. (1998b) findings, clipping udder hair of all cows every year was associated with lower HSCC for herds within the medium and high SCC categories.

In 2 instances, divergent significant associations were reported within a study (not reported in Table 3). Mattresses in dry-cow cubicles were associated with greater odds of being a medium SCC herd than a low or high SCC herd (Barkema et al., 1998b). Cows were moved to the calving pen earlier before calving in medium SCC 
herds than in low or high SCC herds (Barkema et al., 1998b).

\section{Automatic Milking Systems}

Eight studies specifically investigated the effect of milking with an automatic milking system (AMS; Klungel et al., 2000; van der Vorst and Hogeveen, 2000; Rasmussen et al., 2001, 2002; Billon and Tournaire, 2002; van der Vorst et al., 2002, 2003; van der Vorst and Ouweltjes, 2003). In these studies, contrasts were made between periods before and after installation of the AMS, between herds milking with an AMS and a conventional milking system, and between years of installation of the AMS. For studies conducted within the same country, data from herds used in earlier studies were most often reused in more recent studies in addition to data from newer AMS users. Results are presented only for the most recent and complete data sets.

In 262 Dutch and 99 Danish AMS herds, geometric mean BMSCC in the period following AMS installation (period ranged from the first 6 to 18 mo following installation) was significantly higher than that before installation (period ranged from the preceding 6 mo to preceding 4 yr before installation). For all generations of AMS, Dutch herds had geometric mean BMSCC after AMS installation of 204,000 cells/mL compared with 170,000 cells/mL before, and Danish herds had 279,000 cells $/ \mathrm{mL}$ after installation compared with 259,000 cells/mL before (van der Vorst et al., 2002). No significant difference in BMSCC before and after introduction of AMS was seen for 33 German herds, with geometric mean BMSCC before of 201,000 cells/ $\mathrm{mL}$ and after of 203,000 cells/mL (van der Vorst et al., 2002). The German AMS herds that agreed to participate in this study, however, were a relatively small proportion (25\%) of all German herds using an AMS at that time compared with $90 \%$ for Danish AMS herds and $80 \%$ for Dutch AMS herds. In a similar study on $46(23 \%)$ of the 200 French dairies equipped with AMS, no significant difference in BMSCC was found between AMS and conventional milking herds (Billon and Tournaire, 2002). In that study, herds using AMS had a mean BMSCC of 230,000 cells/mL before installation compared with 244,000 cells $/ \mathrm{mL}$ after installation.

Similar changes of BMSCC over time following AMS installation were seen for all generations of AMS in Denmark, Germany, and the Netherlands: an increased BMSCC was observed just after introduction of the AMS followed by a slow decrease over time, with AMS herds reaching a BMSCC level comparable to that of conventional milking herds within 12 to 18 mo of installation (van der Vorst et al., 2002). In the Danish and
German AMS herds, no association between year of installation of the AMS and change in BMSCC over time during the period following installation could be seen. In the 262 Dutch herds, however, AMS installed between January 1, 1998, and March 31, 1999 (defined as second-generation AMS) had BMSCC levels comparable to that of conventional milking herds in the first $6 \mathrm{mo}$ and in the 12- to 18-mo periods following installation. The Dutch herds using other generations of AMS, however, had a significantly higher BMSCC than conventional herds for up to 18 mo following installation.

In a study by Rasmussen et al. (2001) conducted earlier on 69 Danish AMS herds, the BMSCC increase after installation of the AMS could be explained, in part, by a significantly increased incidence of cows going from less than to more than 200,000 cells $/ \mathrm{mL}$. In this study, cumulative incidence went from $10 \%$ in the year before installation to $15 \%$ in the year after installation, leading to a prevalence of cows with BMSCC $>200,000$ cells $/ \mathrm{mL}$ of $35 \%$ before to $39 \%$ after installation $(P<0.01)$. In Denmark, dairy producers changing from conventional to AMS milking were offered participation in a self-monitoring program to help them accomplish the transition between systems. This selfmonitoring program relied mostly on detection followed by treatment or culling of clinically infected and high SCC cows both before and during the milking system transition (Rasmussen et al., 2002). Herds enrolled on this self-monitoring program, like herds not enrolled, had significantly higher BMSCC in the year following installation of the AMS compared with the year before installation; however, they had a significantly lower increase in BMSCC than herds not enrolled (Rasmussen et al., 2002). In these Danish AMS herds, no significant influence of the monitoring program on the incidence of new high SCC cows could be highlighted (Rasmussen et al., 2001).

In a study by van der Vorst and Ouweltjes (2003), BMSCC in the year preceding the transition to an AMS was identified as an important predictor of the BMSCC in the year following installation (38\% of variation explained) and of change in BMSCC after the transition ( $10 \%$ of variation explained). In this same study, dairy producers waiting longer before replacing milk liners and waiting for a system indication to change them had, respectively, a higher BMSCC and a greater BMSCC increase in the year following transition to an AMS. On the other hand, BMSCC was significantly lower on AMS farms where teats were cleaned more than once ( $15 \mathrm{~s}$ each time). In addition, herds where cleaning of the AMS was set automatically and where udders were shaved at least twice a year had a smaller increase in BMSCC in the year following transition to 
the AMS. Finally, when adjusting for the adaptation period by excluding the first 6 mo following the transition to AMS, herds for which the floor of the waiting area was cleaned with an automatic scraper and herds in which additional mechanical ventilation was used had significantly lower BMSCC (van der Vorst et al., 2003).

\section{DISCUSSION}

\section{Methodological Strengths and Limitations}

The most valuable outcome of this systematic review was perhaps the ability to identify practices that have shown consistent associations with SCC in different populations, under different circumstances, and across time. Demonstrating consistency of an association is not related in any way to significance testing methods and, in this regard, the analytical methods used in this review were very appropriate for this purpose (Rothman et al., 2008). Demonstrating consistency of an association is a clear step toward the identification of cause and effect. The practices that have shown a consistent association with SCC possibly had a larger effect on SCC, were efficient under different production settings, or were efficient against the most commonly encountered mastitis pathogens. For these reasons, they should be part of our initial recommendations to any dairy producer.

Lack of consistency, on the other hand, cannot be used to rule out a cause and effect association. Numerous studies did not report any effect estimate for management practices that yielded what the authors considered to be a nonsignificant association. Many of the practices discussed in this review therefore had their associations with SCC completely reported in few, often only one, manuscripts. The binomial test used is certainly biased to some extent by these unreported results. Moreover, the different treatments of confounding effects that were used in different studies could have led to the reporting of different directions of association, thus leading to an apparent inconsistency of the results reported. This apparent inconsistency would be caused by the presence of residual confounding of the observed associations in some studies and not in others, rather than being caused by ineffectiveness of a specific management practice. With that many studies being conducted over such a large period in many different countries, we can expect that several different confounders are somehow operating. The practices that have not shown consistent associations with SCC should therefore not be completely ruled out. Further research would, however, be advocated on these practices or on their conditions of application.
The manuscripts selected in this systematic review represent an important piece of the published literature on associations between management practices applied on dairy farms and SCC. Our specific average herd size and milk production inclusion criteria, however, did restrict the studies selected and careful readers should, therefore, restrict the application of these results to similar dairy herds. The decision to select only studies for which the interventions were applied to or in which observations were made on the entire herd was driven by the need to evaluate evidences for management practices that have been tested in a manner similar to how they would be applied as interventions. Studies excluded because of interventions being applied to a few individuals within a herd do provide ample knowledge on mastitis but clearly cannot fully demonstrate the generalized herd-level applicability of an intervention. Some potentially important manuscripts were excluded for purely logistical reasons: linguistic limitations and failure to obtain important information from authors. Linguistic limitations are a common feature of most published systematic reviews (Moher et al., 2007). In our study, considering the retention percentage of the English, French, and Dutch abstracts (1.1\%), the probability of excluding an important manuscript because of linguistic restrictions was very low $(0.2 \%)$. The resulting potential linguistic bias was therefore, in our opinion, very limited. Failure to obtain important missing information from authors is potentially a more important problem. The 6 manuscripts excluded for this reason had otherwise good potential for being included in this review. It might be argued, however, that incomplete reporting of information highlighted them as poorer quality studies. Although these studies could not be included, they are nonetheless listed to inform readers of additional potentially useful information.

A major limitation of this review was the need to focus on the direction of associations rather than on the magnitude of associations. This limitation resulted mainly from the lack of comparability between studies. The analysis approach used was for this reason very rudimentary; it would classify odds ratios of both 0.30 and 0.90 as "associated with lower SCC" and weight equally all studies regardless of sample size and standard error. On the other hand, transformation of the results from the different studies on a common scale would have required an extensive amount of supplemental information and, with many of the retained studies having been published more than a decade ago, this alternative was simply not feasible.

All of the studies selected were observational studies and nearly all used cross-sectional or before-and-after study designs, which typically do not provide the highest level of evidence. Observational studies are often 
hypothesis-generating, and the causality of the associations highlighted by such studies should be further explored using experimental designs. In our review no experimental studies conducted at the herd level could be found. For many of the practices discussed, however, results have been published from experimental studies conducted at the cow level, with animals or sometimes quarters within a herd being randomized to control and treatment groups. Also, for some practices, experimental studies at the herd or cow level have been conducted but with udder health outcomes other than SCC. To better understand the significance of the associations reported in this review, we recommend evaluating published results from such experimental studies in addition to the consistency of association reported.

Although experimental studies conducted at the herd level are rather uncommon, we nevertheless expected to find a certain number of observational studies using sounder study designs such as cohort and case-control designs. A major problem encountered with cross-sectional study designs is the impossibility to record time order of occurrence between exposure and outcome, leading to the risk of wrongfully highlighting reverse associations between management practices and SCC. As an example, producers having a herd with a high SCC might be more likely to include fore-stripping in their milking procedures to detect clinical mastitis cases. A cross-sectional study design would only highlight the association between fore-stripping and higher SCC, an association that is correct but can certainly not be interpreted as causal.

\section{Management Practices and SCC}

Relatively few of the numerous management practices investigated demonstrated consistent associations with SCC. Furthermore, many of the practices frequently recommended in mastitis control programs had a limited amount of published information available on their effectiveness in a conventional dairy setting, with many showing inconsistent directions of association with SCC across studies. One must bear in mind though, that many of the practices proposed in mastitis control programs are intended primarily to prevent clinical mastitis rather than a high HSCC. Independence between these 2 udder health components has been highlighted before (Barkema et al., 1998a; Olde Riekerink et al., 2008) and practices affecting one or the other component could therefore differ.

In relation to milking procedures, the body of literature supports that milkers should definitely wear gloves during milking, use (well-adjusted) automatic milking unit take-offs, and apply postmilking teat disinfection. Furthermore, high SCC cows and clinical mastitis cases should be milked last. Using a specific milking unit for these cows or rinsing, cleaning, or disinfecting the unit after these cows are milked and before first-lactation cows are milked were studied only once and were associated with higher SCC. The milking parlor should be kept clean and good performance of the milking system should be ensured by having the system inspected at least annually. Although keeping cows standing after milking seemed to be associated with lower SCC in many studies, the findings of Lievaart et al. (2007) highlighted some of the conditions (seasons) potentially limiting the general utility of this practice. In their study, no biological explanation of the observed season effect on this practice could be proposed; they did however recognize, as did others (Barkema et al., 1998b; Barnouin et al., 2004; De Vliegher et al., 2004), the effect of herd manager attitudes on herd SCC. Associations between dairy producer attitudes, management practices used, and udder health have been reported before (Barkema et al., 1999; Jansen et al., 2009). It is probable that many of the effect estimates reported by the selected studies are strongly confounded by herd managers' attitudes; associations observed with lower SCC may in fact be the result of having a knowledgeable and motivated herd manager, which may in turn be associated with both the use of a technique to keep cows standing following milking and lower SCC (through other management techniques). Results from a recent study measuring the association between individual cow postmilking standing time and IMI incidence (thus not confounded by herd manager attitude) seemed to confirm this hypothesis (DeVries et al., 2010). In that study, increasing postmilking standing time was in fact associated with a higher IMI incidence. In another study measuring the association between incidence of IMI by coagulase-negative staphylococci and delivery of feed around milking, a strategy commonly used to promote longer standing time following milking, an increased IMI incidence was again observed for herds using the practice (Dufour et al., 2008).

Few housing-related interventions yielded very consistent associations with SCC. Based on the combined results of several studies, a sound recommendation is to use a freestall housing system with sand-bedded cubicles. Such a modification of the housing system, however, is clearly not a minor correction. A needed modernization of the existing facilities on a farm, however, should be seen as an opportunity to recommend this type of housing system. Cleanliness or frequency of cleaning of the calving pen was the only other management practice related to housing that could be consistently associated with SCC.

From our results, the best-supported recommendations remain to administer an approved intramammary 
antibiotic treatment to all cows at dry-off. Selective antibiotic treatment at dry-off is not consistently associated with lower SCC. The criteria used to select cows to be treated were not discussed in studies of selective dry-off treatment. The efficiency of a selective treatment is certainly determined by the correct selection of the cows to be treated and therefore specification of the selection criteria would have been crucial. One must bear in mind, however, the dual objectives of a dry-cow antibiotic treatment: prevention of new IMI during the dry period and cure of existing IMI (Dingwell et al., 2003). Although it might be relatively easy to select cows to be treated to achieve the second objective, it will always be difficult, if not impossible, to accurately select and treat the cows that would otherwise have acquired a new IMI. The first objective of a dry-cow antibiotic treatment can therefore hardly be fulfilled by a selective dry-cow treatment alone, and the merit of a selective dry-cow treatment is probably heavily determined by the pathogen-specific dry period IMI incidence rate of the herds using it.

Daily inspection of udders of dry cows to detect mastitis during the dry period was also consistently associated with lower SCC. Such an inspection, however, if not coupled with a specific and practical intervention, would not lead to reduced herd SCC. Similarly, use of the CMT was continuously associated with lower SCC. No details concerning any interventions associated with these practices could be found in the studies reporting these associations, and it is possible that the associations observed were again an indirect measure of the effect of a superior dairy producer attitude toward controlling mastitis. Also, frequent clipping or flaming of udder hairs and parenteral supplementation with selenium were consistently associated with lower herd SCC.

The attitude of the dairy producer toward culling needs to be modified to achieve lower SCC. To reduce their herd SCC, dairy producers need to have proactive and well-defined culling strategies based on udder conformation, teat lesions, and clinical mastitis cases rather than simply reacting to udder health events with the result being a greater number of cows culled for mastitis and high SCC (Bareille et al., 1998; Barkema et al., 1998a,b; Barnouin et al., 2004; Rodrigues et al., 2005).

In many studies, an attempt to measure associations between specific components of the diet and SCC was made and very conflicting results were obtained. In these studies, the effects on SCC of the different components of the ration were always estimated independently, without taking into account the interaction of a component with the other elements of the diet. It is obvious that the effect of feeding a specific type of feed, mineral, or supplement is absolutely determined by the presence or absence of other components of a diet. Furthermore, this effect is dependent on the current herd status for the nutrient in question; feeding an additional amount of concentrates will usually be beneficial to energy-deprived cows but could be harmful to well-fed cows. As another example, vitamin E can have either an oxidant or antioxidant effect depending on the cow's initial vitamin E status (Bouwstra et al., 2010). Therefore, studying the association of SCC with any individual component of the diet in such a manner is not very instructive.

Similarly, many studies reported associations between different components of the milking system and SCC. Again, inconsistent results were observed and they might be the result of the inappropriate partition into its measurable constituents of a system that can only be correctly assessed as a whole.

Only a few relatively recent studies investigated calf and heifer management as risk factors for elevated SCC. It is well accepted that an important proportion of heifers already has an IMI at the moment of their first calving (Oliver and Mitchell, 1983; Pankey et al., 1991; Fox et al., 1995). Although many of these IMI may be of short duration, the resulting elevated SCC observed early in the lactation is often associated with elevated SCC throughout the whole lactation (De Vliegher et al., 2004; Paradis et al., 2010). Because a rather high proportion of herds is usually composed of first-lactation cows, the effect of these IMI on herd SCC cannot be ignored. It is interesting to observe that, although practices used from birth to first calving were investigated, most of the practices significantly associated with heifers' early lactation SCC were interventions used during the few weeks before and around calving time. This relatively short period is potentially of great importance for acquisition of new IMI, and further research to understand the risks and mechanisms of IMI and host response in this specific period should be undertaken.

\section{Automatic Milking System}

The introduction of AMS in dairy production is relatively recent and growing interest in this new technology exists. Although the use of an AMS cannot directly be considered an udder health control strategy, AMS can nonetheless affect the choice and condition of application of milking procedures, on mastitis monitoring, and, therefore, on SCC. An augmentation of the BMSCC following installation of an AMS has not been observed in every country but it has been reported often, and herds having an already elevated BMSCC before installation of the AMS seemed more at risk of 
experiencing such an augmentation and to a greater magnitude (Billon and Tournaire, 2002; van der Vorst et al., 2002; van der Vorst and Ouweltjes, 2003). To prevent or reduce such an adverse effect, dairy producers should focus their efforts on reducing their herd SCC before an AMS is put into place. To achieve this objective they could, similarly to the recommendations made in the Danish self monitoring program, intensify the detection and culling of problematic cows beforehand (Rasmussen et al., 2001, 2002). One of the major difficulties encountered with AMS is to correctly sort milk from high SCC cows and clinical mastitis cases; the treatment or culling of some of these cows before installation of the AMS is therefore a sound recommendation. In one study, however, a part of the increase in herd SCC could be explained by an increase number of new high SCC cows (Rasmussen et al., 2001). The increase in SCC seemed therefore to be explained not only by the milking of problematic cows but also by an increased number of new IMI following implementation of the AMS technology. Practices used once the AMS is in place should therefore also be addressed. At this time, little is known of practices associated with SCC in AMS herds; dairy producers who were more aggressive regarding maintenance and cleaning of the AMS seemed able to mitigate the SCC elevation. Efficiency of the AMS teat cleaning methods is another key point that could limit a SCC augmentation (van der Vorst et al., 2003; van der Vorst and Ouweltjes, 2003). Future research on AMS should be aimed at identifying risk factors associated with the incidence of IMI, rather than those associated with IMI prevalence.

\section{CONCLUSIONS}

A large number of management practices have shown consistent associations with herd-level SCC when used in usual dairy settings. These practices should be the cornerstone of udder health recommendations to dairy producers. Although many management practices have shown interesting associations with SCC, the lack of consistency observed should moderate reliance on their use.

\section{REFERENCES}

Abdi, H. 2007. Bonferroni and Sidak corrections for multiple comparisons. Pages 103-106 in Encyclopedia of Measurement and Statistics. N. J. Salkind, ed. Sage, Thousand Oaks, CA.

Bach, A., N. Valls, A. Solans, and T. Torrent. 2008. Associations between nondietary factors and dairy herd performance. J. Dairy Sci. 91:3259-3267.

Bareille, N., H. Seegers, C. Fourichon, F. Beaudeau, and X. Malher. 1998. Survenue et expression des mammites cliniques et subcliniques en troupeaux bovins laitiers: Facteurs de risque liés à la conception et à l'utilisation du bâtiment. Pages 297-300 in Rencontres
Autour des Recherches sur les Ruminants. Institut de l'élevage, Paris, France.

Bareille, N., H. Seegers, M. B. Kiebre-Toe, F. Beaudeau, and C. Fourichon. 2000. Risk factors for elevated milk somatic cell counts during early lactation in dairy heifers. Pages 509-514 in Proceedings of the 10th International Congress on Animal Hygiene, Maastricht, the Netherlands. Animal Health Services, Maastricht, the Netherlands

Barkema, H. W., Y. H. Schukken, T. J. G. M. Lam, M. L. Beiboer, G. Benedictus, and A. Brand. 1998b. Management practices associated with low, medium, and high somatic cell counts in bulk milk. J. Dairy Sci. 81:1917-1927.

Barkema, H. W., Y. H. Schukken, T. J. G. M. Lam, M. L. Beiboer, H. Wilmink, G. Benedictus, and A. Brand. 1998a. Incidence of clinical mastitis in dairy herds grouped in three categories by bulk milk somatic cell counts. J. Dairy Sci. 81:411-419.

Barkema, H. W., J. D. Van der Ploeg, Y. H. Schukken, T. J. Lam, G. Benedictus, and A. Brand. 1999. Management style and its association with bulk milk somatic cell count and incidence rate of clinical mastitis. J. Dairy Sci. 82:1655-1663.

Barnouin, J., M. Chassagne, S. Bazin, and D. Boichard. 2004. Management practices from questionnaire surveys in herds with very low somatic cell score through a national mastitis program in France. J. Dairy Sci. 87:3989-3999.

Bartlett, P. C., G. Y. Miller, S. E. Lance, and L. E. Heider. 1992. Environmental and managerial determinants of somatic-cell counts and clinical mastitis incidence in Ohio dairy herds. Prev. Vet. Med. 14:195-207.

Bewley, J., R. W. Palmer, and D. B. Jackson-Smith. 2001. A comparison of free-stall barns used by modernized Wisconsin dairies. J. Dairy Sci. 84:528-541.

Billon, P., and F. Tournaire. 2002. Impact of automatic milking systems on milk quality and farm management: The French experience. Pages V59-V63 in 1st N. Am. Conf. Robotic Milking, Toronto, ON, Canada. Wageningen Press, Wageningen, the Netherlands.

Bouwstra, R. J., M. Nielen, and T. van Werven. 2010. Which dairy dry cows need to be supplemented with vitamine $\mathrm{E}$ to reduce mastitis? Pages 94-99 in 5th IDF Mastitis Conference: Mastitis Research into Practice. VetLearn, Christchurch, New Zealand.

De Vliegher, S., H. Laevens, H. W. Barkema, I. R. Dohoo, H. Stryhn, G. Opsomer, and A. de Kruif. 2004. Management practices and heifer characteristics associated with early lactation somatic cell count of Belgian dairy heifers. J. Dairy Sci. 87:937-947.

DeVries, T. J., S. Dufour, and D. T. Scholl. 2010. Relationship between feeding strategy, lying behavior patterns, and incidence of intramammary infection in dairy cows. J. Dairy Sci. 93:1987-1997.

Dingwell, R. T., D. F. Kelton, and K. E. Leslie. 2003. Management of the dry cow in control of peripartum disease and mastitis. Vet. Clin. North Am. Food Anim. Pract. 19:235-265.

Dohoo, I. R., and K. E. Leslie. 1991. Evaluation of changes in somatic cell counts as indicators of new intramammary infections. Prev. Vet. Med. 10:225-237.

Dufour, S., H. W. Barkema, L. DesCôteaux, T. J. DeVries, I. R. Dohoo, K. Reyher, J. P. Roy, and D. T. Scholl. 2010. Development and validation of a bilingual questionnaire for measuring udder health related management practices on dairy farms. Prev. Vet. Med. 95:74-85.

Dufour, S., I. R. Dohoo, T. J. DeVries, and D. T. Scholl. 2008. Improving mastitis control programs through identification of risk factors related to the incidence of subclinical intramammary infections. Pages 211-218 in Mastitis Control: From Science to Practice. Wageningen Academic Publishers, the Hague, the Netherlands.

Ellis, K. A., G. T. Innocent, M. Mihm, P. Cripps, W. G. McLean, C. V. Howard, and D. Grove-White. 2007. Dairy cow cleanliness and milk quality on organic and conventional farms in the UK. J. Dairy Res. 74:302-310.

Erskine, R. J., and R. J. Eberhart. 1991. Post-milking teat dip use in dairy herds with high or low somatic cell counts. J. Am. Vet. Med. Assoc. 199:1734-1736.

Erskine, R. J., R. J. Eberhart, L. J. Hutchinson, and R. W. Scholz. 1987b. Blood selenium concentrations and glutathione peroxidase 
activities in dairy herds with high and low somatic cell counts. J. Am. Vet. Med. Assoc. 190:1417-1421.

Erskine, R. J., R. J. Eberhart, L. J. Hutchinson, and S. B. Spencer. 1987a. Herd management and prevalence of mastitis in dairy herds with high and low somatic cell counts. J. Am. Vet. Med. Assoc. 190:1411-1416.

Follmann, D., P. Elliott, I. Suh, and J. Cutler. 1992. Variance imputation for overviews of clinical trials with continuous response. J Clin. Epidemiol. 45:769-773.

Fox, L. K., S. Chester, J. Hallberg, S. Nickerson, J. Pankey, and L. Weaver. 1995. Survey of intramammary infections in dairy heifers at breeding age and first parturition. J. Dairy Sci. 78:16191628.

Fulwider, W. K., T. Grandin, D. J. Garrick, T. E. Engle, W. D. Lamm, N. L. Dalsted, and B. E. Rollin. 2007. Influence of free-stall base on tarsal joint lesions and hygiene in dairy cows. J. Dairy Sci. 90:3559-3566.

Goodger, W. J., J. C. Galland, and V. E. Christiansen. 1988. Survey of milking management practices on large dairies and their relationship to udder health and production variables. J. Dairy Sci. 71:2535-2542.

Greenhalgh, T., and R. Peacock. 2005. Effectiveness and efficiency of search methods in systematic reviews of complex evidence: Audit of primary sources. BMJ 331:1064-1065.

Gygax, L., and D. Nosal. 2006. Contribution of vibration and noise during milking to the somatic cell count of milk. J. Dairy Sci. 89:2499-2502.

Hogeveen, H., J. D. Miltenburg, S. Den Hollander, and K. Frankena. 2001. Milking three times a day and its effect on milk production and udder health. Bull. Int. Dairy Fed. 367:7.

Hutton, C. T., L. K. Fox, and D. D. Hancock. 1990. Mastitis control practices: Differences between herds with high and low milk somatic cell counts. J. Dairy Sci. 73:1135-1143.

Hutton, C. T., L. K. Fox, and D. D. Hancock. 1991. Risk-factors associated with herd-group milk somatic-cell count and prevalence of coagulase-positive staphylococcal intramammary infections. Prev. Vet. Med. 11:25-35.

Jansen, J., B. H. P. van den Borne, R. J. Renes, G. van Schaik, T. J. G. M. Lam, and C. Leeuwis. 2009. Explaining mastitis incidence in Dutch dairy farming: The influence of farmers' attitudes and behaviour. Prev. Vet. Med. 92:210-223.

Jayarao, B. M., S. R. Pillai, A. A. Sawant, D. R. Wolfgang, and N. V. Hegde. 2004. Guidelines for monitoring bulk tank milk somatic cell and bacterial counts. J. Dairy Sci. 87:3561-3573.

Khaitsa, M. L., T. E. Wittum, K. L. Smith, J. L. Henderson, and K. H. Hoblet. 2000. Herd characteristics and management practices associated with bulk-tank somatic cell counts in herds in official Dairy Herd Improvement Association programs in Ohio. Am. J. Vet. Res. 61:1092-1098.

Khan, K. S., R. Kunz, J. Kleijnen, and G. Antes. 2003. Systematic reviews to support evidence-based medicine: How to review and apply findings of healthcare research. Royal Society of Medicine Press Ltd, London, UK.

Klungel, G. H., B. A. Slaghuis, and H. Hogeveen. 2000. The effect of the introduction of automatic milking systems on milk quality. J. Dairy Sci. 83:1998-2003.

Köster, G., B. A. Tenhagen, and W. Heuwieser. 2006a. Factors associated with high milk test day somatic cell counts in large dairy herds in Brandenburg. I: Housing conditions. J. Vet. Med. A Physiol. Pathol. Clin. Med. 53:134-139.

Köster, G., B. A. Tenhagen, N. Scheibe, and W. Heuwieser. 2006b. Factors associated with high milk test day somatic cell counts in large dairy herds in Brandenburg. II. Milking practices. J. Vet. Med. A Physiol. Pathol. Clin. Med. 53:209-214.

Lievaart, J. J., H. W. Barkema, W. D. J. Kremer, J. van den Broek, J. H. M. Verheijden, and J. A. P. Heesterbeek. 2007. Effect of herd characteristics, management practices, and season on different categories of the herd somatic cell count. J. Dairy Sci. 90:4137-4144.
Moher, D., J. Tetzlaff, A. C. Tricco, M. Sampson, and D. G. Altman. 2007. Epidemiology and reporting characteristics of systematic reviews. PLoS Med. 4:e78.

Nyman, A. K., U. Emanuelson, A. H. Gustafsson, and K. P. Waller. 2009. Management practices associated with udder health of firstparity dairy cows in early lactation. Prev. Vet. Med. 88:138149.

O'Rourke, K., and S. Greenland. 2008. Meta-Analysis. Pages 652-682 in Modern Epidemiology. K. J. Rothman, S. Greenland, and T. L. Lash, ed. Lippincott Williams \& Wilkins, Philadelphia, PA.

Olde Riekerink, R. G. M., H. W. Barkema, D. F. Kelton, and D. T. Scholl. 2008. Incidence rate of clinical mastitis on Canadian dairy farms. J. Dairy Sci. 91:1366-1377.

Oliver, S. P., and B. Mitchell. 1983. Intramammary infections in primigravid heifers near parturition. J. Dairy Sci. 66:1180-1183.

Pankey, J. W., P. Drechsler, and E. Wildman. 1991. Mastitis prevalence in primigravid heifers at parturition. J. Dairy Sci. 74:15501552.

Paradis, M.-E., E. Bouchard, F. Miglior, and J.-P. Roy. 2010. Impact of non-clinical Staphylococcus aureus or coagulase-negative staphylococci intramammary infection during the first month of lactation on SCC and milk yield in heifers. J. Dairy Sci. 93:2989-2997.

Philbrook, H. T., N. Barrowmann, and A. X. Garg. 2007. Imputing variance estimates do not alter the conclusions of a metaanalysis with continuous outcomes: A case study of changes in renal function after living kidney donation. J. Clin. Epidemiol. 60:228-240.

Rasmussen, M. D., M. Bjerring, P. Justesen, and L. Jepsen. 2002. Milk quality on Danish farms with automatic milking systems. J. Dairy Sci. 85:2869-2878.

Rasmussen, M. D., J. Y. Blom, L. A. H. Nielsen, and P. Justesen. 2001. Udder health of cows milked automatically. Livest. Prod. Sci. $72: 147-156$.

Rodrigues, A. C., D. Z. Caraviello, and P. L. Ruegg. 2005. Management of Wisconsin dairy herds enrolled in milk quality teams. J. Dairy Sci. 88:2660-2671.

Rothman, K. J., S. Greenland, C. Poole, and T. L. Lash. 2008. Causation and causal inference. Pages 5-26 in Modern Epidemiology. K. J. Rothman, S. Greenland, and T. L. Lash, ed. Lippincott Williams \& Wilkins, Philadelphia, PA.

Smith, J. W., and L. O. Ely. 1997. The influence of feeding and housing systems on production, reproduction, and somatic sell count scores of southern Holstein herds. Prof. Anim. Sci. 13:155-161.

Smith, J. W., L. O. Ely, W. M. Graves, and W. D. Gilson. 2002. Effect of milking frequency on DHI performance measures. J. Dairy Sci. 85:3526-3533.

Stup, R. E., J. Hyde, and L. A. Holden. 2006. Relationships between selected human resource management practices and dairy farm performance. J. Dairy Sci. 89:1116-1120.

Svensson, C., A. K. Nyman, K. P. Waller, and U. Emanuelson. 2006. Effects of housing, management, and health of dairy heifers on first-lactation udder health in Southwest Sweden. J. Dairy Sci. 89:1990-1999.

van der Vorst, Y., K. Bos, W. Ouweltjes, and J. Poelarends. 2003. Milk quality on farms with an automatic milking system: Farm and management factors affecting milk quality. Report D9 of the EU Project. Implications of the introduction of automatic milking on dairy farms (QLK5-2000-31006). Accessed July 5, 2010. http:// www.automaticmilking.nl/

van der Vorst, Y., and H. Hogeveen. 2000. Automatic milking systems and milk quality in the Netherlands. Pages 73-82 in Proceedings of the International Symposium Robotic Milking, Lelystad, the Netherlands. Wageningen Press, Wageningen, the Netherlands.

van der Vorst, Y., K. Knappstein, and M. D. Rasmussen. 2002. Milk quality on farm with an automatic milking system. Effects of automatic milking on the quality of produced milk. Report D8 EU Project. Implications of the introduction of automatic milking on dairy farms (QLK5 2000-31006). Accessed July 5, 2010. http:// www.automaticmilking.nl 
van der Vorst, Y., and W. Ouweltjes. 2003. Milk quality and automatic milking; A risk inventory. Report 28. Accessed July 5, 2010. http://www.pv.wur.nl.

Vecht, U., H. J. Wisselink, and P. P. Defize. 1989. Dutch national mastitis survey. The effects of herd and animal factors on somatic cell count. Neth. Milk Dairy J. 43:425-435.

Weiss, W. P., J. S. Hogan, K. L. Smith, and K. H. Hoblet. 1990. Relationships among selenium, vitamin $\mathrm{E}$, and mammary gland health in commercial dairy herds. J. Dairy Sci. 73:381-390.
Wenz, J. R., S. M. Jensen, J. E. Lombard, B. A. Wagner, and R. P. Dinsmore. 2007. Herd management practices and their association with bulk tank somatic cell count on United States dairy operations. J. Dairy Sci. 90:3652-3659.

Wilson, D. J., R. N. Gonzalez, and P. M. Sears. 1995. Segregation or use of separate milking units for cows infected with Staphylococcus aureus: Effects on prevalence of infection and bulk tank somatic cell count. J. Dairy Sci. 78:2083-2085. 